UDK: 621.791

DOI: https://doi.org/10.24867/05AM01Radovanovic

\title{
УТИЦАЈ ПАРАМЕТАРА РОБОТСКОГ НАВАРИВАЊА НА ОСОБИНЕ ИЗРАБЕНОГ ЕЛЕМЕНТА КОНСТРУКЦИЈЕ ОД ЧЕЛИКА 3355
}

\section{INFLUENCE OF ROBOTIC HARDFACING PARAMETERS ON PROPERTIES OF THE S355 STRUCTURAL STEEL S355 FABRICATED ELEMENT}

Милан Радовановић, Себастиан Балош, Факултет техничких наука, Нови Сад

\section{Област - МАШИНТВО}

Кратак садржај - У раду је извршено експериментално наваривање додатног материјала SG2 слој по слој на плочу од конструкционог челика уз помоћ робота. Израђена су три узорка са различитим параметрима и смеровима наваривања. Добијени наварени слојеви су визуелно испитани, испитани су макро пресеци, а извршено је и испитивање затезањем, савијањем и енергија удара. Испитивањем је утврђено да параметри као што су мана струја и напон уз оптималну брзину наваривања као и наизменичног смера наваривања значајно утичу на механичке особине материјала и геометрију добијеног елемента.
\end{abstract}

Кључне речи: роботско заваривање, МАГ наваривање, механичке особине, WАAM технологија.

Abstract: In this work, experimental welding of the consumable material SG2 layer per layer on a plate of structural steel with the aid of robots was carried out. Three samples were created with different parameters and welding directions. The obtained welded joints were visually tested, macro cross-sections were examined, and tensile testing, bending, and impact energy tests were performed. The experiment found that parameters such as lower current and voltage with the optimal welding speed and the alternating welding direction significantly influence the mechanical properties of the material and geometry of the material.

Keywords: robot welding, GMAW hardfacing, mechanical properties, WAAM technology

\section{1. УВОД}

Заваривање је технологија спајања два или више, истих или различитих материјала, топљењем или притиском, са или без додавања додатног материјала. Поступци заваривања, који се најчешће користе у пракси, засновани су на локалном загревању материјала изнад температуре топљења, када заварени спој настаје очвршћавањем (електролучно), или на локалном загревању заварени спој настаје уз додатно деловање притиска [1].

\section{НАПОМЕНА:}

Овај рад проистекао је из мастер рада чији ментор је био др Себастиан Балош, ванр. проф.
Наваривање је процес наношења површинског слоја на метални део да би се повећала његова отпорност према абразији, ерозији, ударцима или неком другом облику оптерећења. Процес наваривања је у практичном смислу исти као заваривање, с тим да је његова намена другачија. Основна разлика у односу на метализацију је топљење површине основног материјала и његово мешање са додатним материјалом. За наваривање се највише користи E, МИГ И ТИГ поступак, а кад је потребно нанети слој на што већу површину примењује се ЕПП или експлозивни поступак [2]. Предмет разматрања овог рада је нова технологија наваривања WAAMАдитивна производња електричним луком и жицом. WAAM је једна од технологија са највећом брзином наношења материјала, знатно већом у односу на селективно ласерско синтеровање, при чему је цена опреме значајно нижа. Заснива се на наваривању слоја на претходни слој помоћу робота са извором за заваривање и додавачем жице. Користи се за наваривање великих, скупих металних делова са сложеном геометријом у појединачној производњи или у малим серијама, при чему је једино ограничење у величини производа радни простор робота.

\section{2. ЕКСПЕРИМЕНТАЛНИ РАД}

За наваривање као основни материјал коришћене су плоче од конструкционог челика $\mathrm{S} 355 \mathrm{~J} 2+\mathrm{N}$ дебљине 8 мм, димензија 400 мм $\times 100$ мм, а као додатни материјал жица SG2 произвођача Thyssen energomag, пречника 1,2 мм у заштитном гасу C18 (Ar 82\% CO2 $18 \%)$.

Табела 1. Називни хемијски састав жице SG2 (EN ISO 14341-A-G 424 C1/M21 3Sil)

\begin{tabular}{|c|c|c|c|c|c|c|c|c|}
\hline \% & \%Si & \%Mn & \%P & \%S & \% Cu & \% Cr & \% Ni & \% Ti \\
\hline 0,07 & 0,85 & 1,45 & 0,02 & 0,02 & 0,25 & $<0,15$ & $<0,15$ & $<0,05$ \\
\hline
\end{tabular}

Табела 2. Механичка својства наноса жицяом SG2 (EN ISO 14341-A-G 424 C1/M21 3Sil)

\begin{tabular}{|c|c|c|}
\hline $\begin{array}{l}\text { 3aтезна чврстоһа } \\
\text { Rm }\end{array}$ & $\begin{array}{c}\text { Напон течења Re } \\
{[\mathbf{M P a}]}\end{array}$ & $\begin{array}{c}\text { Издужење A } \\
{[\%]}\end{array}$ \\
\hline [MPa] & 450 & $>24$ \\
\hline 550 & & \\
\hline
\end{tabular}


Поступак израде узорака спроведен је на роботској ћелији FANUC Robot ARC Mate 100iC/8L у фирми Proficut у Бачком Петровцу. За извор струје за наваривање коришћен је уређај EWM Phoenix puls $500 \mathrm{~A}$ са воденим хлађењем.

Димензије узорака су $200 \mathrm{Mм} \times 80 \mathrm{Mм} \times 5-10$ мм. Први узорак је рађен са путањом горионика само у једном смеру и увек са исте тачке у којој се успостављао електрични лук. Путање пиштоља за наваривање преостала два узорка биле су наизменичне, тј. први пролаз с лева у десно, следећи с десна у лево, и тако наизменично.

Током израде зидова, односно приликом наваривања сваког слоја очитавани су параметри наваривања (јачина струје и напон).

Након наваривања сваког пролаза помичним мерилом измерена је висина зида и очишћена је горња површина са паузама између сваког пролаза око 2-3 мин. Код израде првог зида (узорак 1) коришћен је гас $\mathrm{Ar} 82 \%$ i CO2 18\% . Брзина заваривања је била константна и износила је $7 \mathrm{~mm} / \mathrm{sec}$. Слободни крај жице је $14 \mathrm{~mm}$, а проток гаса $15 \mathrm{l} / \mathrm{min}$. Остали параметри заваривања, као што су: јачина струје, напон , висина сваког пролаза и унесена топлота, приказани су у табели 3.

Табела 3. Параметри наваривана првог зида

\begin{tabular}{|c|c|c|c|c|c|}
\hline Пролаз & $\begin{array}{c}\text { Висина, } \\
{[\mathrm{mm}]}\end{array}$ & $\begin{array}{c}\text { Јачина } \\
\text { струје, } \\
\text { [A] }\end{array}$ & $\begin{array}{c}\text { Hanон, } \\
{[\mathbf{V}]}\end{array}$ & $\begin{array}{c}\text { Брзина } \\
\text { жице } \\
{[\mathrm{m} / \mathrm{min}]}\end{array}$ & $\begin{array}{c}\text { Унесена } \\
\text { топлота, } \\
{[\mathrm{kJ} / \mathrm{cm}]}\end{array}$ \\
\hline 1. & 3 & 160 & 23,9 & 6 & 4,37 \\
\hline 2. & 5 & 150 & 23,4 & 5,5 & 4,01 \\
\hline 3. & 6,7 & 140 & 23 & 5 & 3,68 \\
\hline 4. & 8,2 & 131 & 22,5 & 4,5 & 3,36 \\
\hline 5. & 9,8 & 121 & 22,1 & 4 & 3,05 \\
\hline 6. & 11,3 & 107 & 21,3 & 3,5 & 2,60 \\
\hline 50. & 77,3 & 107 & 21,3 & 3,5 & 2,60 \\
\hline 51. & 78,5 & 107 & 21,3 & 3,5 & 2,60 \\
\hline 52. & 80 & 107 & 21,3 & 3,5 & 2,60 \\
\hline
\end{tabular}

Код израде другог зида (узорак 2) коришћен је гас $\mathrm{Ar}$ $82 \% \mathrm{CO}_{2}$ 18\%. Брзина заваривања је константна и износи $10 \mathrm{~mm} / \mathrm{sec}$. Слободни крај жице је $15 \mathrm{~mm}$, а проток плина $15 \mathrm{l} / \mathrm{min}$. Остали параметри заваривања приказани су у табели 4.

Табела 4. Параметри наваривања другог зида

\begin{tabular}{|c|c|c|c|c|c|}
\hline Пролаз & $\begin{array}{c}\text { Висина, } \\
{[\mathbf{m m}]}\end{array}$ & $\begin{array}{c}\text { Јачина } \\
\text { струje, } \\
{[\mathbf{A}]}\end{array}$ & $\begin{array}{c}\text { Напон, } \\
{[\mathbf{V}]}\end{array}$ & $\begin{array}{c}\text { Брзина } \\
\text { жице } \\
{[\mathbf{m} / \mathbf{m i n}]}\end{array}$ & $\begin{array}{c}\text { Унесена } \\
\text { топлота, } \\
{[\mathbf{k J} / \mathbf{c m}]}\end{array}$ \\
\hline 1. & 2,5 & 160 & 23,9 & 6 & 3,05 \\
\hline 2. & 4,4 & 160 & 23,9 & 6 & 3,05 \\
\hline 3. & 5,6 & 160 & 23,9 & 6 & 3,05 \\
\hline 4. & 6,8 & 160 & 23,9 & 6 & 3,05 \\
\hline 5. & 8 & 160 & 23,9 & 6 & 3,05 \\
\hline 54. & 78,5 & 160 & 23,9 & 6 & 3,05 \\
\hline 55. & 80 & 160 & 23,9 & 6 & 3,05 \\
\hline 56. & 81 & 160 & 23,9 & 6 & 3,05 \\
\hline
\end{tabular}

Код израде трећег зида (узорак 3) коришћен је исти гас. Брзина заваривања је константна и износи 13 $\mathrm{mm} / \mathrm{sec}$. Слободни крај жице је $15 \mathrm{~mm}$, а проток плина 15 l/min. Остали параметри заваривања приказани су у табели 5 .
Табела 5. Параметри наваривања трећег зида

\begin{tabular}{|c|c|c|c|c|c|}
\hline Пролаз & $\begin{array}{c}\text { Висина, } \\
{[\mathbf{m m}]}\end{array}$ & $\begin{array}{c}\text { Јачина } \\
\text { струje, } \\
{[\mathbf{A}]}\end{array}$ & $\begin{array}{c}\text { Напон, } \\
{[\mathbf{V}]}\end{array}$ & $\begin{array}{c}\text { Брзина } \\
\text { жице } \\
{[\mathbf{m} / \mathbf{m i n}]}\end{array}$ & $\begin{array}{c}\text { Унесена } \\
\text { топлота, } \\
{[\mathbf{k J} / \mathbf{c m}]}\end{array}$ \\
\hline 1. & 2,5 & 184 & 23,7 & 7 & 2,68 \\
\hline 2. & 4,3 & 184 & 23,7 & 7 & 2,68 \\
\hline 3. & 5,8 & 184 & 23,7 & 7 & 2,68 \\
\hline 4. & 7 & 184 & 23,7 & 7 & 2,68 \\
\hline 5. & 8,4 & 184 & 23,7 & 7 & 2,68 \\
\hline 59. & 79,5 & 184 & 23,7 & 7 & 2,68 \\
\hline 60. & 80,9 & 184 & 23,7 & 7 & 2,68 \\
\hline 61. & 81,6 & 184 & 23,7 & 7 & 2,68 \\
\hline
\end{tabular}

Мора се напоменути да су сва три узорка рађена на температури око $0^{\circ}$ целзијуса, као и да се хала која није имала грејање периодично отварала и проветравала током саме израде узорака, па се доводи упитање утицај промаје, повећане влажности као и смрзавање гаса у боци. Након наваривања извршено је испитивање узорака у Лабараторији за испитивање материјала на Факултету техничких наука у Новом Саду. Поступак испитивања је урађен у складу са стандардом SRPS EN ISO 15614. Извршено је макро испитивање, испитивање затезањем, савијањем и енергија удара. Поступак испитивања узорака на затезање и на савијање је урађен на једноосној машини за затезање тј. кидалици типа ВЕБ ЗДМ 5/91. Испитивање жилавости је рађено на инструментираном Шарпијевом клатну JWT-450 у радном опсегу 450 J. При испитивању макро структуре у оба случаја извршено је исецање узорака са брусилицом, након тога извршено је постепено брушење са шмирглом класе p80 па до p2500, након тога је извршено полирање узорака и нагризање које је рађено са $3 \%$ ниталом (3\% азотна киселина HNO3 у алкохолу).

\section{3. РЕЗУЛТАТИ}

\section{1 Резултати макро испитивања}

Макро анализа рађена је на сва три узорка што се може видети са слике 1.

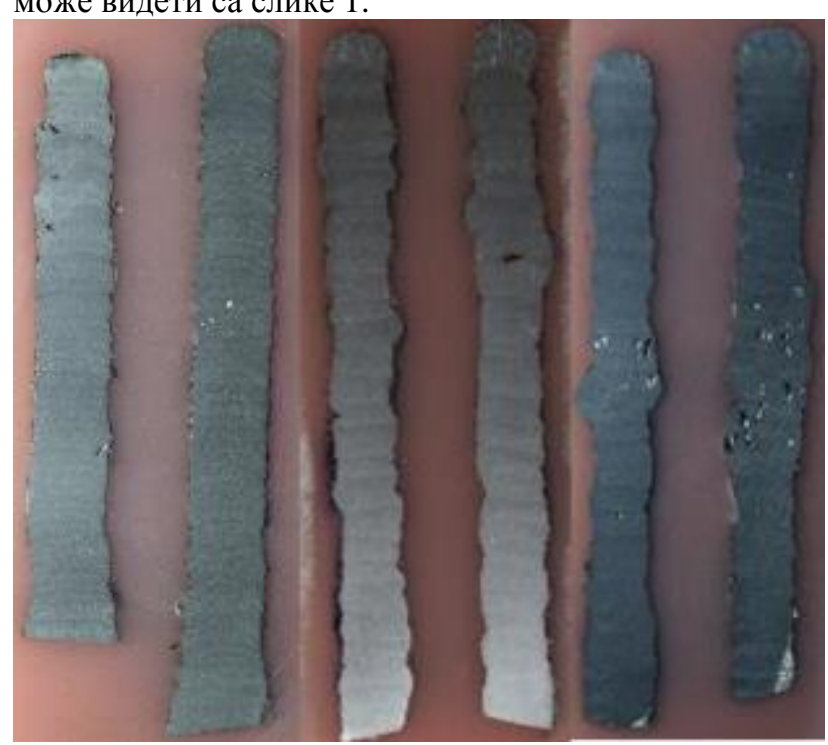

a)

б)

в)

Слика 1. Макро испитивање: а) узорак 1, б) узорак 2, в) узорак 3 
Прегледом макроструктуре уочена је нагнутост на сва три узорка, а посебно се истиче на узорку 2 и 3 . На узорку 1 се види равномерније слагање слојева у односу на друга два узорка, док је на месту завршетка лука најмањи прираштај висине што се може видети са слике а) леви узорак.

На последњем пролазу код сва три узорка могу јасно видети стубасти кристали. Видљива је порозност на сва три узорка а највећа је уочена на узорку 3 .

\section{2 Резултати испитивања затезањем}

Резултати испитивања узорака на затезање приказани су у табели 6. На основу резултата може да се констатује да је највећа добијена вредност напона течења и затезне чврстоће постигнута на узорку 2 као и средња вредност која одговара прописаном стандарду EN10025. Најнижа вредност напона течења и затезне чврстоће добијена је на узорку 3.

Код свих узорака који су испитивани затезањем дошло је до лома епрувете на различитим местима, уз претходно формирање врата на епрувети насталог услед деформације затезањем. На слици 2 приказана је епрувета и изглед лома након испитивања узорка затезањем.

Табела 6. Резултати испитивања затезањем

\begin{tabular}{|c|c|c|c|c|}
\hline Узорак & Епрувета & $\begin{array}{c}\boldsymbol{R}_{p} \\
{[\mathrm{MPa}]}\end{array}$ & $\begin{array}{c}\boldsymbol{R}_{\mathbf{m}} \\
{[\mathrm{MPa}]}\end{array}$ & $\begin{array}{c}\mathrm{A} \\
{[\%]}\end{array}$ \\
\hline \multirow{4}{*}{1} & 11 & 439 & 484 & 28 \\
\hline & 13 & 455 & 518 & 30 \\
\hline & 17 & 402 & 500 & 32 \\
\hline & $\begin{array}{c}\text { Ср. } \\
\text { вредност }\end{array}$ & 432 & 501 & 30 \\
\hline \multirow{4}{*}{2} & 21 & 488 & 536 & 26 \\
\hline & 23 & 465 & 543 & 30 \\
\hline & 27 & 466 & 540 & 28 \\
\hline & $\begin{array}{c}\text { Cр. } \\
\text { вредност }\end{array}$ & 473 & 539 & 28 \\
\hline \multirow{4}{*}{3} & 31 & 242 & 252 & 6 \\
\hline & 33 & 396 & 443 & 35 \\
\hline & 37 & 451 & 473 & 12 \\
\hline & $\begin{array}{c}\text { Ср. } \\
\text { вредност }\end{array}$ & 363 & 389 & 18 \\
\hline \multicolumn{2}{|c|}{$\begin{array}{l}\text { Механичке особине } \\
\text { челика S355J2+N по } \\
\text { стандарду EN10025 }\end{array}$} & $355-550$ & $490-630$ & $>22$ \\
\hline
\end{tabular}

\section{3 Резултати испитивања савијањем}

Резултати испитивања видљиви су на узорцима са слике 3. где су приказана два узорка један најбољи и један најлошији. На основу резултата датих у табели 7. може да се констатује да код узорка 1 испитиваног савијањем преко лица није дошло до појаве прслине тј.отварања епрувете, док је код узорка 3 дошло до отварања.

Остали узорци из групе узорака 1 су имали чисту површину без прслина. Док код узорака из групе 3 постоји велика порозност код свих узорака па при

деловању силе унутрашњи напони немају довољну јачину да се супроставе деформацији и долази до отварања.

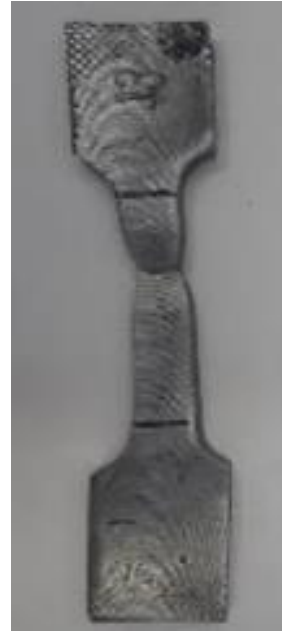
a)

Слика 2. Изглед епрувете након испитивања затезағем: а) узорак 1, б) узорак 2 , в) узорак 3

Табела 7. Резултати испитаних узорака на савијање

\begin{tabular}{|c|l|}
\hline Узорак 1 & Прслина мања од 2 мм \\
\hline Узорак 2 & $\begin{array}{l}\text { Четири прслине мање од 1 мм са спољне } \\
\text { стране, шест мањих од 2 мм са унутрашње }\end{array}$ \\
\hline Узорка 3 & Велика порозност на свим узорцима \\
\hline
\end{tabular}

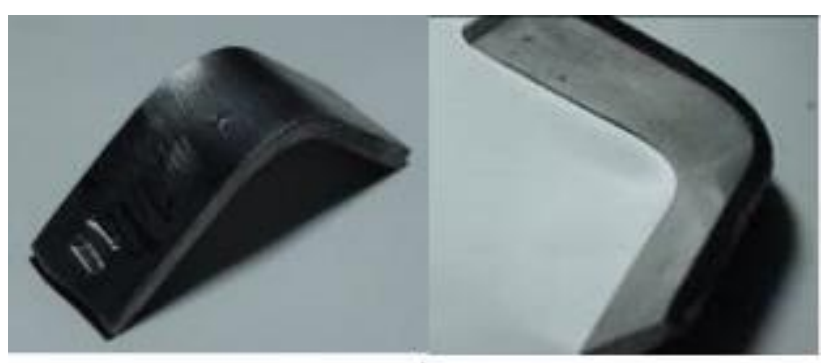

a)

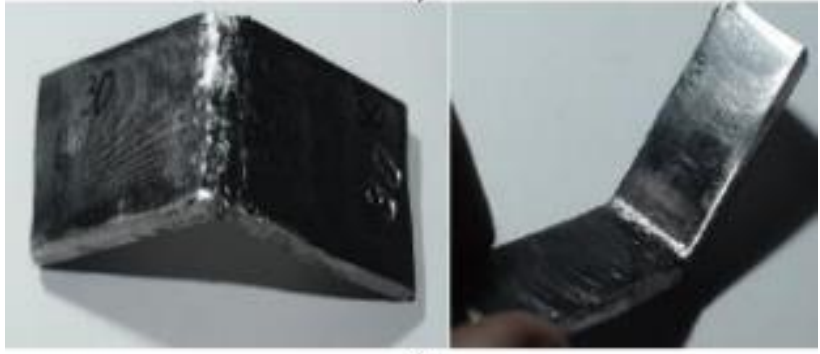

6)

Слика 3. Узорици након испитивања на савијање: а) узорак 1, б) узорак 3

\section{4 Резултати испитивања енергије удара}

Са слике се види да узорак 1 у односу на друга два узорка поседује веће вредности жилавости материјала.

Мале вредности узорка 3 можемо преписати порозној структури која је последица спољашњих фактора и нешто већим вредностима параметара заваривања. 


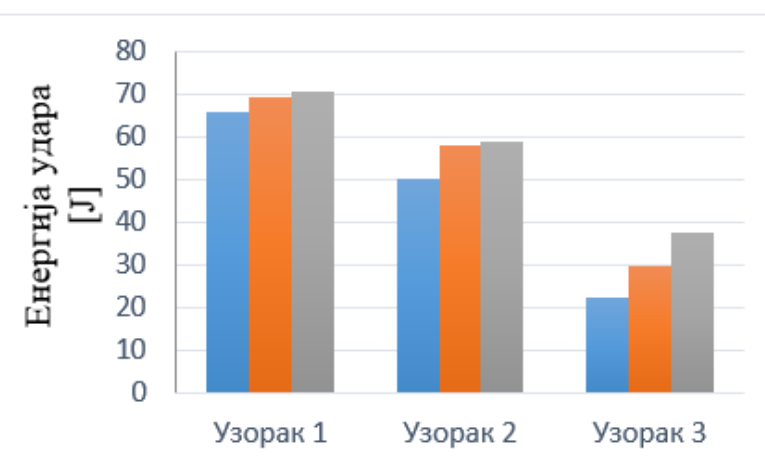

Слика 4. Вредности енергије удара за сва три узорка

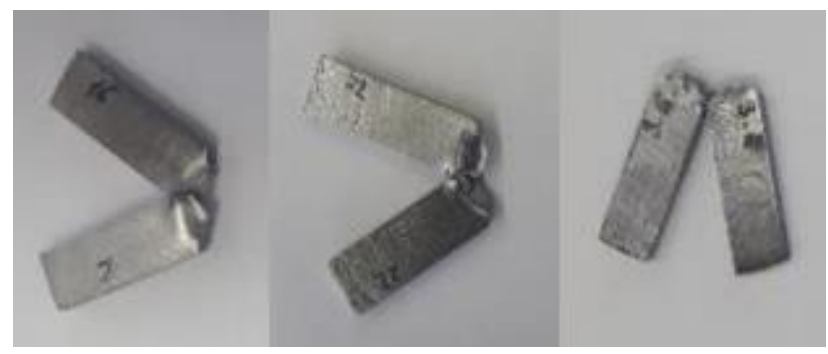

Слика 5. Узоричи након испитивања на Шарпију

\section{4. ДИСКУСИЈА}

При испитивању узорака на затезање израчунате су средње вредности за сва три узорка и упоређене са стандардним прописаним вредностима за конвенционално произведен челик основе на коју је извршено наваривање (ваљане плоче), тако да се узорци 1 и 2 налазе у прописаним вредностима за $\mathrm{Rp}, \mathrm{Rm}$ и $\mathrm{A}$, док се код узорка 3 једино напон течења налази у прописаним вредностима.

Током испитивања на савијање најмања прслина се јавила на узорку 1 док код других узорака добијених из узорка 1 нису јавиле прслине. На свим узорцима из узорка 3 се јасно види порозност што је довело до отварања материјала. Такође се јасно види да је узорак 3 има најмање вредности при испитивању на енергију удара, што значи да је жилавост на том узорку најслабија.

При макро испитивању јасно се види да на узорку 3 узорци имају највише изражену порозност, као и гемотријуску нетачност. У табели 8. приказано је поређење просечне висине сваког слоја и просечног уноса топлоте код узорака. Из таблице је видљиво да код узорка 1 имамо нешто већу просечну висину у односу на друга два узорка.

Такође видимо да је унос топлоте узорка 1 сличан узорку 3 иако су параметри наваривања напон, струја и брзина наваривања различити. Може се констатовати да је највећа вредност просечне висине слоја код узорка 1 у односу на друга два узорка добијена због утицаја мале јачине струје као и нижег напона лука.

То значи да када су вредности веће од оптималних долази до већег претапања предходног слоја као и цурења са стране.
Табела 8. Просечна висина слоја и унесена топлота за сва три узорка

\begin{tabular}{|c|c|c|}
\hline Узорак & $\begin{array}{c}\text { Просечна висина } \\
\text { слоја, }[\mathrm{mm}]\end{array}$ & $\begin{array}{c}\text { Просечан унос } \\
\text { топлоте, }[\mathrm{kJ} / \mathrm{cm}]\end{array}$ \\
\hline Узорак 1 & 1,54 & 2,71 \\
\hline Узорак 2 & 1,45 & 3,05 \\
\hline Узорак 3 & 1,34 & 2,68 \\
\hline
\end{tabular}

\section{5. ЗАКЉУЧАК}

На основу спроведених испитивања и анализа резултата може се закључити следеће:

- Током анализе резултата може се приметити да су најбољи резултати добијени на узорку 1 и 2, па се може закључити да мала јачина струје са оптималном брзином заваривања и напоном омогућава WAAM технологији мањи број пролаза до задате висине, бољу распоређеност растопа, мање прскање и изливање, као и готово минималну порозност. Треба напоменути да је узорак 1 рађен у једном правцу и да је јасно видљив утицај топлоте на почетку заваривања и на крају па је и сама геометрија узорка другачија у односу на друга два узорка која су рађена са наизменичним наваривањем.

- На узорку 3 је уочена знатно већа порозност и већи број пролаза као и веће прскање у односу на остала два узорка. Сматра се да је разлог те порозности већа брзина заваривања, већа јачина струје и напона као и утицај средине.

\section{6. ЗАХВАЛНОСТ}

Резултати презентовани у овом раду су реализовани у оквиру пројекта „Истраживање и примена савремених метода карактеризације материјала и заварених спојева у производном машинству “, Департмана за производно машинство, ФТН Нови Сад.

\section{7. ЛИТЕРАТУРА:}

[1] Палић В., Сабо Б.: Технологија заваривања, Факултет техничких наука, Нови Сад 2003

[2] Група аутора: Поступци заваривања и опрема за заваривање (наваривање), Завод за заваривање, број док.: 1.14. стр. 1, 2004.

[3] Стандард SRPS EN ISO 15614-1:2017

\section{Кратка биографија:}

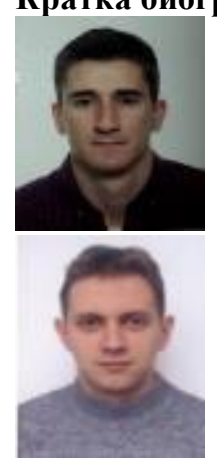

Милан Радовановић рођен у Новом Саду 1992. године. Мастер рад на Факултету техничких наука из области Машинство Материјали и технологије спајања одбранио је 2019. године.

Проф. др. Себастиан Балош рођен је у Сомбору 1974. год. Докторирао је на Факултету техничких наука 2010. год., а 2016. год. је биран у звање ванредног професора из уже научне области Материјали и технологија спајања. 